\title{
The emerging landscape of circular RNAs in immunity: breakthroughs and challenges
}

Zhouxiao $\mathrm{Li}^{1 \dagger}$, Ye Cheng ${ }^{2 \dagger}$, Fan $\mathrm{Wu}^{2 \dagger}$, Liangliang $\mathrm{Wu}^{2}$, Hongyong $\mathrm{CaO}^{2^{*}}$, Qian Wang ${ }^{2^{*}}$ and Weiwei Tang ${ }^{2^{*}}$

\begin{abstract}
Circular RNAs (circRNAs) are covalently linked RNAs that exhibit individual strand with a closed-loop framework compared with a conserving, steady and abundant linear counterpart. In recent years, as high-throughput sequencing advancement has been developing, functional circRNAs have been increasingly recognized, and more extensive analyses expounded their effect on different diseases. However, the study on the function of circRNAs in the immune system remains insufficient. This study discusses the basic principles of circRNAs regulation and the systems involved in physiology-related and pathology-related processes. The effect of circRNAs on immune regulation is elucidated. The ongoing development of circRNAs and basic immunology has multiplied their potential in treating diseases. Such perspective will summarize the status and effect of circRNAs on various immune cells in cancer, autoimmune diseases and infections. Moreover, this study will primarily expound the system of circRNAs in T lymphocytes, macrophages and other immune cells, which creates a novel perspective and lay a theoretical basis for treating diseases.
\end{abstract}

Keywords: circRNAs, Immunity;T lymphocytes;macrophages;infection

\section{Introduction}

Circular RNAs (circRNAs) are an emerging RNAs type differing from traditional linear RNAs. They are abundant in eukaryotic transcriptome and form covalently closed continuous loops, where the $3^{\prime}$ and $5^{\prime}$ ends presenting in an RNA molecule in a normal manner are joined jointly [1]. Such characteristic induces the property of circRNAs, covering microRNA(miRNA) sponge, showing an interaction to RNA-binding proteins (RBPs), and encoding proteins that has been recently identified [2]. CircRNAs are found to impact considerable physiological and pathology processes, covering regulated cell death, metabolism, cancer, as well as drug resistance [35]. Besides, circRNAs can be up-regulated and stable in exosomes, which has increased opportunities for

\footnotetext{
*Correspondence: caohongy6167@163.com; wqian1205@163.com; 1243773473twww@sina.com

${ }^{\dagger}$ Zhouxiao Li, Ye Cheng and Fan Wu contributed equally to this work. ${ }^{2}$ Department of General Surgery, Nanjing First Hospital, Nanjing Medical University, Nanjing, Jiangsu, China

Full list of author information is available at the end of the article
}

intercellular communication [6]. The dysregulation of circRNA expression is closely associated with the occurrence of a wide range of diseases in human beings. Indeed, the current research and reports of circRNAs in the field of cancer are the most.

The immune system accounts for maintenance of internal homeostasis by immune regulations, by monitoring and preventing the invasiveness of pathogens. The immune response of the synthesis of multiple immune cells elicits antiviral, antibacterial and antitumor functions. Though existing researchers have more focused on proteins, numerous researches suggested that noncoding RNAs may also be considered novel candidates helping regulate immune diseases and responses $[7,8]$. It has been newly evidenced that circRNAs participate in immune responses, though their effect remains unclear. Here, we primarily elucidated the status and effect of circRNAs on a wide variety of types of immune cells in cancer, autoimmune diseases, and infections, which can

(c) The Author(s). 2020 Open Access This article is licensed under a Creative Commons Attribution 4.0 International License, which permits use, sharing, adaptation, distribution and reproduction in any medium or format, as long as you give appropriate credit to the original author(s) and the source, provide a link to the Creative Commons licence, and indicate if changes were made. The images or other third party material in this article are included in the article's Creative Commons licence, unless indicated otherwise in a credit line to the material. If material is not included in the article's Creative Commons licence and your intended use is not permitted by statutory regulation or exceeds the permitted use, you will need to obtain permission directly from the copyright holder. To view a copy of this licence, visit http://creativecommons.org/licenses/by/4.0/ The Creative Commons Public Domain Dedication waiver (http://creativecommons.org/publicdomain/zero/1.0/) applies to the data made available in this article, unless otherwise stated in a credit line to the data. 
present a novel perspective and lay a theoretical foundation in treating diseases.

\section{Biological functions of circRNAs}

Recently conducted researches indicated that circRNAs can be used as a miRNA sponge to inhibit targeted mRNA functions, showing interaction to RNA-binding proteins (RBPs) and translating proteins [9]. Among them, the functional effect of miRNA sponge is the most extensively known. However, binding to other proteins and translating proteins have established novel directions to study circRNAs.

\section{MiRNA sponge}

MiRNAs are small ( $21 \mathrm{nt})$ non-coding RNAs identified in some viruses, animals and plants, inhibiting translation of messenger RNAs that participate in significant and different biology-related processes. For the presence of different binding sites recognizing a seed region, circRNAs can sponge up a family's miRNAs, thus becoming relatively efficient inhibiting elements and then releasing target mRNAs [10]. The Argonaute protein (Ago) family are the "effector proteins" that promote miRNAs to fulfill the effects, as well as being the core factors of RNA silencing. They can bind to a range of small non-coding RNAs categorizes (covering miRNAs) and get involved in the suppressing process for mRNA cleavage or translating process [11]. It has been reported that many circRNAs reduce the ability of miRNAs by binding to target mRNA via being a binding basis in terms of Ago2 and miRNA (Fig. 1).

\section{Interacting with RBPs}

RBPs are proteins undertaking gene transcribing and translating processes together with circRNAs and impact circRNA processing, folding, and localization [12] (Fig. 1). For instance, in Drosophila melanogaster, Mbl protein can promote the formation of circRNA by binding to introns on the exon flanks [13]. During epithelialmesenchymal transition, under the relatively high expression of QKI protein, mRNA is formed, and the highly expressed QKI protein is capable of binding to the intron flanking the exon, making the exons side by side to promote cyclization [14]. In contrast to the effect of QKI protein, high expression of ADAR1 protein can inhibit the formation of circRNA by breaking the RNA pairing of exon flanks [15].

\section{Translation of proteins and peptides}

CircRNAs were originally defined as non-coding RNAs. As fueled by the efficient advancement of bioinformatics analysis and high-throughput sequencing techniques, some circRNAs have been found to be able to translate proteins and peptides. CircRNAs covering an open reading frame (ORF) stimulated through an inner ribosome entry site (IRES) have the potential to translate proteins (Fig. 2) [16]. For instance, circZNF609 effectively indicates circRNA translation and covers an ORF spanning the initiation codon and terminating in the in-frame stop codon, so cyclization complies with linear transcript [17]. Moreover, as the most affluent RNA modification in eukaryotes, N6-methyl adenosine (m6A) has been suggested to be closely associated with circRNA mediated protein translation as well. Yang Y et al. reported a

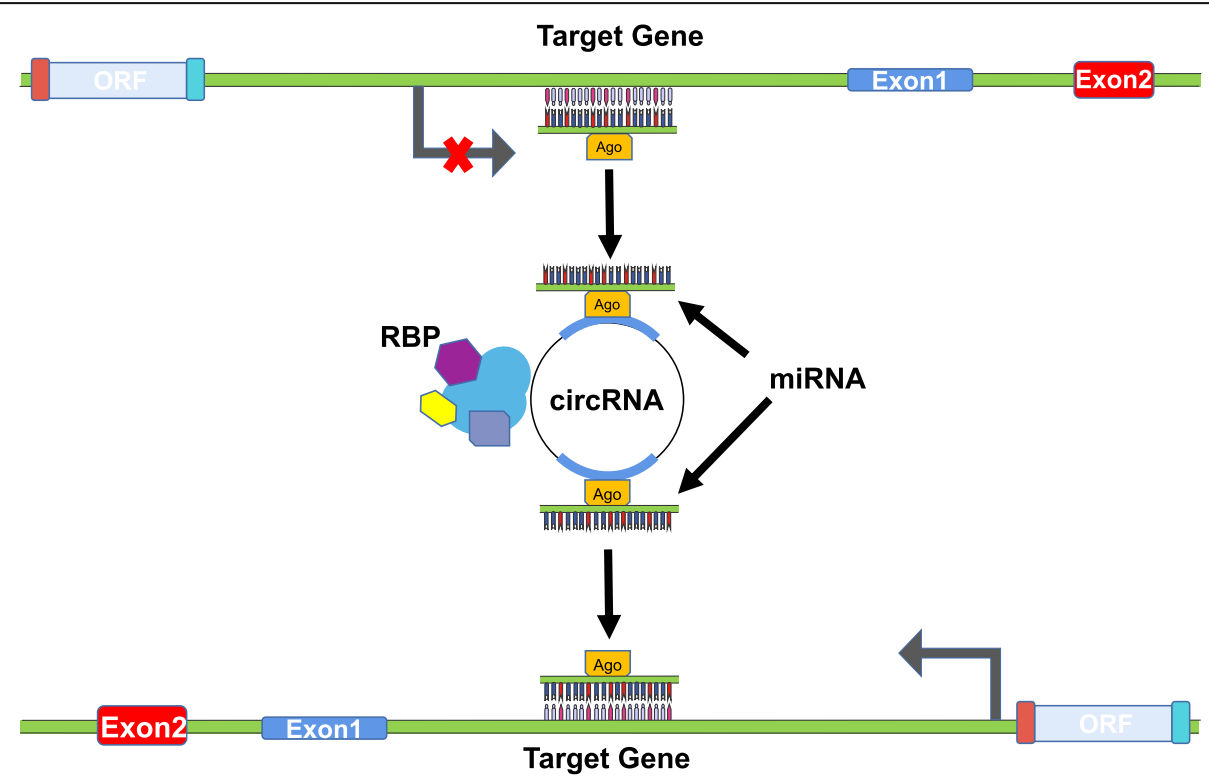

Fig. 1 CircRNAs can reduce the ability of miRNAs to bind to target mRNAs by acting as a binding platform for Ago2 and miRNAs and interact with RBPs 


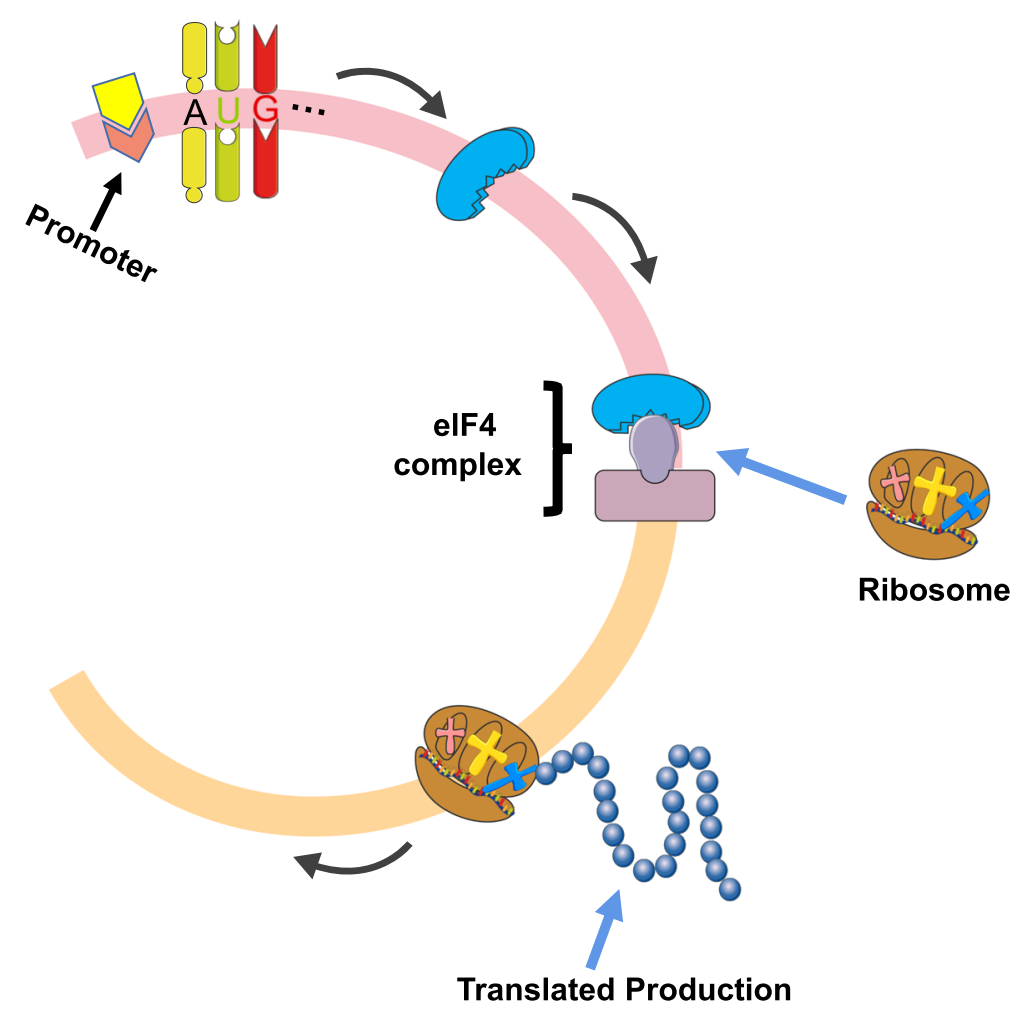

Fig. 2 Translation of circRNAs: a circRNA containing an open reading frame (ORF) driven by the internal ribosome entry site (IRES) can translate a functional protein

recognized m6A motif enrichment on circRNAs, and a single m6A site was found sufficient to initiate translating process. Such translation initiated by $\mathrm{m} 6 \mathrm{~A}$ required the initiation factors eIF4G2 and m6A recognition protein YTHDF3, as enhanced by methyltransferase METTL3/14, hindered by demethylase FTO, and enriched by heat shock [18]. The mentioned outcomes present a novel insight into circRNAs functions in physiological and pathological processes, which also changes the original concept that circRNAs do not participate in protein coding.

\section{Physiology and pathology-related processes with circRNAs involved in}

circRNAs can regulate regulated cell death (RCD)

RCD was employed for expressing the death of cells originating from the intracellular or extracellular microenvironment performed by molecular systems when other adaptive responses cannot restore cell homeostasis, which, according to their different systems, can fall into apoptosis, autophagic cell death, ferroptosis, etc. $[19,20]$ It has been reported that circRNA is capable of regulating RCD especially autophagy and ferroptosis. Autophagy is a mature and conserved system delivering intracellular components and organelles to lysosomes for degradation process [21]. Disorders of autophagy are associated with considerable diseases. Emerging studies revealed a novel circRNA termed as autophagyassociated circular RNA (ACR) to regulate autophagy. This study showed that ACR protected the heart from ischemia/reperfusion injury and narrowed myocardial infarction area. ACR activated Pink1 expressing process by directly binding to Dnmt3B and blocking DNA methylation of Dnmt3B mediated Pink1 promoting element, thus inhibiting autophagy [22]. Ferroptosis has been defined recently as a non-apoptotic, RCD procedure covering the abnormal metabolism of lipid oxides in cells catalyzed by iron ions or iron enzymes [23]. In such process, a wide range of inducers break the cell redox balance and produce considerable lipid peroxidation products, thus triggering cell death. Zhang $\mathrm{HY}$ et al. reported that circ-TTBK2 knockdown or miR-761 increase could retard cell proliferation, invasion, and promote ferroptosis in glioma cells [24]. The above data shows that the effect of circRNAs on RCD requires subsequent exploration, and more specific investigation is required in this aspect, opening more prospects for ongoing and future research.

\section{circRNAs is involved in cell metabolism}

Metabolism Resetting of energy is a hallmark of tumors attributed to genome instable state. According to recently 
conducted researches, circRNAs participate in metabolism covering glycolysis, fatty acid metabolism, and amino acid metabolism. Li Q et al. proved that circMAT2B enriched PKM2 by sponging miR-338-3p, which encoded a vital enzyme during glycolysis and facilitated hepatocellular carcinoma (HCC) progression [25]. Li H's team identified that circ-CUX1 bonded to EWS RNA-binding protein 1 (EWSR1) to expedite its interacting process with MYCrelated zinc finger protein (MAZ), thus leading to promotion of aerobic glycolysis and tumor progression in neuroblastoma [26]. An inverse association between circ 0046366 expressing and triglyceride (TG) level in HepG2 cell culture and liver tissues was identified [27]. Circ 0046366 could sponge miR-34a to protect receptor (PPAR) $\alpha$ stimulated by the peroxisome proliferator from transcriptional repression. PPAR $\alpha$ activated CPT2 and ACBD3 to degrade lipids. Researches also delved into the effect of circRNAs on glutamine metabolism and identified the circ_002581/miR-122/Slc1a5 axis in non-alcoholic steatohepatitis [28].

\section{circRNAs are enriched and stable in exosomes}

Exosomes are endocytic origin's small membrane vesicles enegrated by majority of cells. They cover species of proteins, mRNAs and miRNAs that regulate the behaviors of recipient cells and become biomarkers for the diagnosis of human diseases [29]. Li Y et al. in 2015 first confirmed the existence of considerable circRNAs in exosomes [30]. Next, the association between circRNAs and exosomes began to rise. RNA-seq analysis was conducted for detecting the abundance of circRNAs in exosomes from serum and follicular fluid. Note that Wang $\mathrm{G}$ et al. reported that higher metastatic HCC endowed potential with less or no metastatic potential by exosomes covering circ-PTGR1, thereby leading to stronger migration and invasion of tumor cells [31]. Likewise, exosomal circRNAs secreted by adipocytes have been reported for facilitating tumor development and mitigating DNA impairment via hindering miR-34a and stimulating USP7/cyclin A2 signaling path [32].

\section{circRNAs and drug resistance}

Though existing targeted drugs perform well in malignancy treatment, drug resistance is still inevitable. Therefore, it is extremely crucial to deeply understand the drug resistance system and find new therapeutic target. $\mathrm{Xu} \mathrm{N}$ et al. employed high-throughput circRNA chips to detect the A549-sensitive strain and paclitaxelresistant strain A549 / Taxol. In contrast to the sensitive strains, the expression of 2909 circRNAs in A549 / Taxol was noticeably enriched and 8372 circRNAs were noticeably declined, demonstrating that abnormal circRNA is likely to alter the occurrence of paclitaxel resistance [33].Circ-PVT1 was found to facilitate paclitaxel resistance of gastric cancer cells by controlling ZEB1 expressing via the sponging process for miR-124-3p [34].

\section{circRNAs and cancer}

Note that there are numerous causes of circRNA disorders in cancer (e.g., aberrant cis-elements, aberrant chromosomes and genomes, aberrant transcription, aberrant spliceosomal machinery, and aberrant trans-acting elements) [35]. Liu W et al. illustrated a novel circ_103809 /miR-4302/ZNF121/MYC regulating signaling pathway promotes lung cancer progression [36].Bian LJ et al. and Zhang PL et al. indicated that circ_103809 may be a potential novel gene target for the diagnosis and treatment of colorectal cancer(CRC) by controlling biological functions via the miR-532-3P/FOXO4 axis [37, 38].Song LL et al. suggested an oncogenic role for circ_0007534 in breast cancer through being a miR-593 sponge for enriching MUC19 expression [39] .However, the studies on circRNAs in cancer recurrence and metastasis remain unmatured, and further exploration is required. In this content, a figure was generated for illustrating the angle and direction of circRNA when taking part in physiology- and pathology-related processes (Fig. 3).

\section{Circular RNAs in immune responses and diseases}

The immune system should monitor and defend against a wide variety of exogenous pathogens, and it should maintain internal homeostasis by maintaining appropriate immune tolerance and regulation. In fact, immune surveillance and defense act as the major immune responses. Based on the type of foreign antigen, the immune response can perform antiviral, antibacterial, and anti-tumor functions, depending on the synthesis of a wide range of immune cells that build the immune defense [40-43]. Factors (e.g., improper exposure to autoantigen, maladjustment of immune response and cross-antigen stimulation) may induce autoimmunity and facilitate the progress of several immune diseases [44-46]. Immunity can fall into innate and adaptive immunity. Innate immunity is defined as the first line of host defense against pathogens and gives rise to adaptive immune system to conduct effector functions. The innate immune system is primarily mediated by dendritic cells (DCs), macrophages, and natural killer cells (NKs). A response by innate immunity is induced for the pathogen that gives rise to an antigen-specific adaptive immune response. Adaptive immunity exhibits high specificity and covers primarily $\mathrm{T}$ and $\mathrm{B}$ lymphocytes. CircRNAs were found to facilitate immune responses and impact the processes of autoimmune diseases, tumor immunity and antiviral immunity. In this study, the correlation and regulating systems of circRNAs in a wide variety of immune responses and diseases are summarized (Fig. 4, 5, Table 1) [47-84] . 


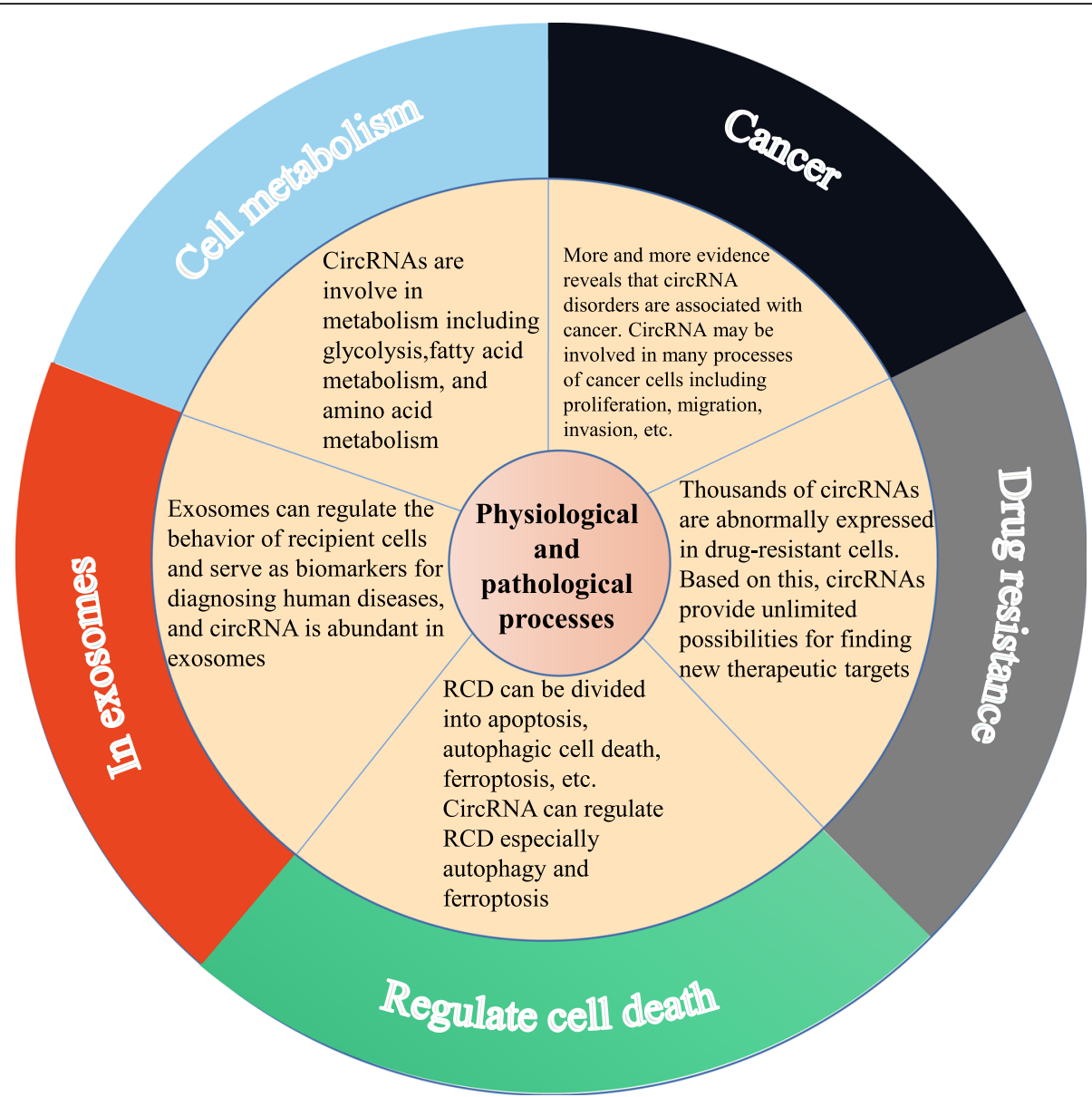

Fig. 3 Physiological and pathological processes that circRNAs involve in

\section{circRNAs and $\mathrm{CD}^{+} \mathrm{T}$ lymphocytes}

$\mathrm{CD} 4^{+} \mathrm{T}$ cells, a vital immune cell in the body's immune mechanism, i.e., the assistant of the immune system, can direct the body against microorganisms (e.g., pathogenic microorganisms). Zhang $\mathrm{C}$ et al. isolated $\mathrm{CD}^{+}{ }^{+} \mathrm{T}$ cells where circRNA microarray study was conducted for screening out circRNA candidates. As indicated from the results, circ_0012919 reduction enriched the expression of DNMT1, decreased the expressions of CD70 and CD11a, and reversed the DNA hypomethylation of CD11a and CD70 in CD4 ${ }^{+} \mathrm{T}$ cells of systemic lupus erythematosus (SLE); however, it was reversible by DNMT1 reduction [51]. Circ_0005519 was reported to be upregulated and negatively related to hsa-let-7a-5p expression in $\mathrm{CD}^{+} \mathrm{T}$ cells of asthmatic cases. The fraction of exhaled nitric oxide ( $\mathrm{FeNO}$ ) and the peripheral blood eosinophil rate were positively related to circ_0005519 expression in $\mathrm{CD}^{+} \mathrm{T}$ cells. Circ_0005519 expressions between $\mathrm{CD}^{+} \mathrm{T}$ cells and PBMCs were harmonious in asthmatic cases. From the mechanistical perspective, circ_0005519 might bind to hsa-let-7a-5p and mitigate inhabitation for IL-13/IL-6 in CD4 ${ }^{+} \mathrm{T}$ cells [50].

\section{circRNAs and CD8 ${ }^{+} \mathrm{T}$ lymphocytes}

$\mathrm{CD} 8^{+} \mathrm{T}$ cells are the most common $\mathrm{T}$ lymphocyte types. Global circRNAs microarray between plasma of cases with $\mathrm{HCC}$ with large $\mathrm{CD}^{+}$tumor-infiltrating lymphocytes (TILs) and small CD8 ${ }^{+}$TILs effectively reported 6 emerging circRNAs exhibiting different expression. To be specific, the expression of circ_0064428 noticeably decreased in HCC patients carrying high $\mathrm{CD}^{+}$TILs whereas it was up-regulated in those patients with low $\mathrm{CD}^{+}$TILs. Besides, circ_0064428 was negatively related to cases' survival, tumor size and metastasis [85]. Wang $\mathrm{YH}$ et al. employed circRNA profiling to investigate circRNA-miRNA interactions in aging human $\mathrm{CD}^{+} \mathrm{T}$ cell groups, alongside the loss of CD28 expression. According to their study, circ_100783 may impact phosphoprotein-associated functions during CD28related $\mathrm{CD}^{+} \mathrm{T}$ cell aging. The overlapped circ_100783 expression is likely to denote an emerging biomarker in terms of the longitudinal tracking of CD28-related CD8 ${ }^{+}$ $\mathrm{T}$ cell aging and global immunosenescence [48]. According to Wang J et al., circ_002178 can facilitate PD-L1 expression by sponging miR-34 in lung adenocarcinoma 

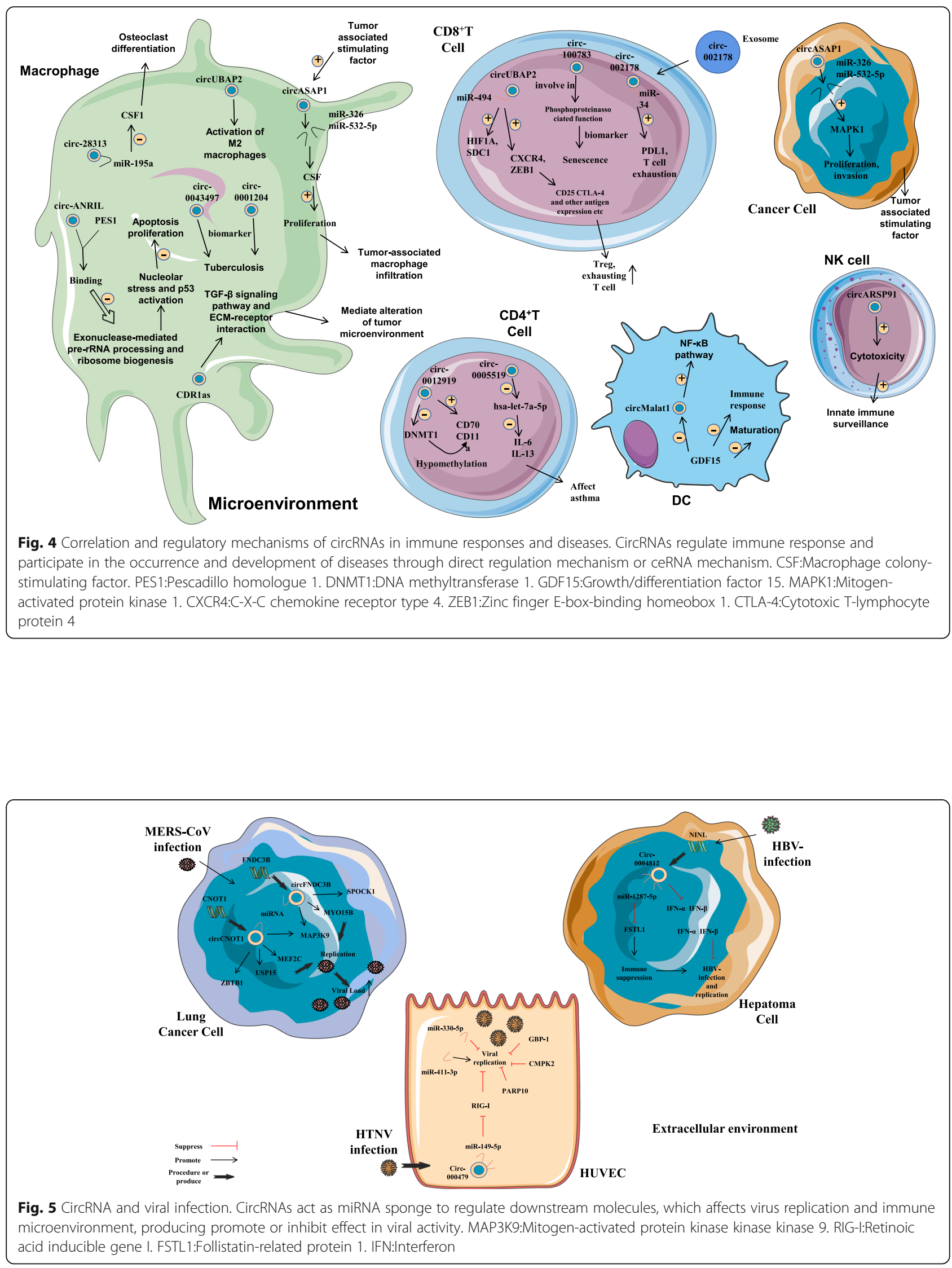
Table 1 circular RNAs in immune responses and diseases

\begin{tabular}{|c|c|c|c|c|}
\hline circRNA & $\begin{array}{l}\text { Immune cell } \\
\text { types }\end{array}$ & Potential Functions & Diseases or Process & Reference \\
\hline $\begin{array}{l}\text { Circ_ } \\
002178\end{array}$ & $\mathrm{CD}^{+} \mathrm{T}$ cell & acting as a ceRNA to promote PDL1/PD1 expression & LUAD & [47] \\
\hline $\begin{array}{l}\text { circ_ } \\
100783\end{array}$ & $\mathrm{CD}^{+} \mathrm{T}$ cell & $\begin{array}{l}\text { playing a role in phosphoprotein-associated functions duringCD28-related CD8 }{ }^{+} \\
T \text { cell ageing }\end{array}$ & - & [48] \\
\hline $\begin{array}{l}\text { circ- } \\
\text { TNFRSF11A }\end{array}$ & $\mathrm{CD}^{+} \mathrm{T}$ cell & participating in the SCID mediated alteration of different signaling pathways. & $\mathrm{SCID}$ & [49] \\
\hline $\begin{array}{l}\text { circ_- } \\
0005519\end{array}$ & $\mathrm{CD}^{+} \mathrm{T}$ cell & $\begin{array}{l}\text { inducing } \mathrm{IL}-13 \text { and } \mathrm{IL}-6 \text { expression by regulating let-7a- } 5 p \text { in } C D 4^{+} \mathrm{T} \text { cells to } \\
\text { affect asthma }\end{array}$ & Asthma & {$[50]$} \\
\hline 0012919 & $\mathrm{CD}^{+} \mathrm{T}$ cell & $\begin{array}{l}\text { increased DNMT1 expression, reduced CD70 and CDIlla expression, rescued the } \\
\text { DNA hypomethylation of CD1 la and CD70 in CD4 }{ }^{+} T \text { cells of SLE patients, as well } \\
\text { as regulated the expression of RANTES and KLF13 by onding to miR-125a-3p }\end{array}$ & SLE & [51] \\
\hline circ-LAMP1 & T cell & $\begin{array}{l}\text { promoting T-cell lymphoblastic lymphoma progression via acting as a ceRNA for } \\
\text { miR-615-5p to regulate DDR2 expression. }\end{array}$ & Lymphoblastic lymphoma & [52] \\
\hline- & T cell & $\begin{array}{l}\text { structure and degradation of circRNAs regulating PKR Activation in innate } \\
\text { immunity }\end{array}$ & - & [53] \\
\hline $\begin{array}{l}\text { circ- } \\
\text { CDR1as/ } \\
\text { ciRS-7 }\end{array}$ & $\begin{array}{l}\mathrm{CD}^{+} \mathrm{T} \text { cell } \\
\text { NK cell } \\
\text { Macrophage }\end{array}$ & $\begin{array}{l}\text { regulating the TGF- } \beta \text { signaling pathway and ECM-receptor interaction to serve as } \\
\text { a mediator in alteration of the tumor microenvironment }\end{array}$ & Cancer & [54] \\
\hline circ-UBAP2 & $\begin{array}{l}\text { Macrophage } \\
\text { Treg } \\
\text { Exhausted T } \\
\text { cells }\end{array}$ & $\begin{array}{l}\text { mediated ceRNA network modulating PAAD by regulating the infiltration and } \\
\text { function of immune cells }\end{array}$ & PAAD & [55] \\
\hline $\begin{array}{l}\text { circ-PAX5 } \\
\text { circ-PVT1 }\end{array}$ & $\begin{array}{l}\text { T cells } \\
\text { B cells }\end{array}$ & $\begin{array}{l}\text { up-regulation in pediatric B-precursor acute lymphoblastic leukemia, and dis- } \\
\text { closed circRNAs with variable expression across cytogenetic subtypes }\end{array}$ & $\begin{array}{l}\text { Pediatric B-precursor acute } \\
\text { lymphoblastic leukemia }\end{array}$ & [56] \\
\hline \multicolumn{5}{|l|}{ circ-HIPK3 } \\
\hline circ-ASAP1 & Macrophage & $\begin{array}{l}\text { circASAP1 promotes HCC cell proliferation and invasion by regulating miR-326/ } \\
\text { miR-532-5p-MAPK1 signaling and, mediates tumor-associated-macrophage infil- } \\
\text { tration by regulating the miR-326/miR-532-5p-CSF-1 pathway }\end{array}$ & $\mathrm{HCC}$ & [57] \\
\hline $\begin{array}{l}\text { circ- } \\
0043497\end{array}$ & Macrophage & $\begin{array}{l}\text { circRNAs alterations are involved in human monocyte derived macrophages } \\
\text { response to Mycobacterium tuberculosis infection. }\end{array}$ & $\begin{array}{l}\text { Mycobacterium } \\
\text { tuberculosis infection }\end{array}$ & [58] \\
\hline \multicolumn{5}{|l|}{$\begin{array}{l}\text { circ_- }_{0} \\
001204\end{array}$} \\
\hline circ-ANRIL & Macrophage & $\begin{array}{l}\text { circANRIL binds to pescadillo homologue } 1 \text { (PES1), thereby impairing } \\
\text { exonuclease-mediated pre-rRNA processing and ribosome biogenesis in vascular } \\
\text { smooth muscle cells and macrophages. }\end{array}$ & $\begin{array}{l}\text { Ribosomal RNA maturation } \\
\text { and atherosclerosis }\end{array}$ & [59] \\
\hline $\begin{array}{l}\text { circ- } \\
\text { HECTD1 }\end{array}$ & Macrophage & $\begin{array}{l}\text { SiO2-activated macrophages promoted fibroblast proliferation and migration via } \\
\text { the circHECTD1/HECTD1 pathway }\end{array}$ & Silicosis & [60] \\
\hline $\begin{array}{l}\text { circ- } \\
\text { CDC42BPA }\end{array}$ & B cell & disrupting transduction of B cell signaling to induce occurrence of SCID & SCID & [61] \\
\hline $\begin{array}{l}\text { Circ- } \\
\text { MALAT1 }\end{array}$ & DC & $\begin{array}{l}\text { GDF15 induces tolerogenic DCs (Tol-DCs) through inhibition of circ-MALAT1 and } \\
\text { the NFKB signaling pathway and up-regulation of IDO }\end{array}$ & - & [62] \\
\hline $\begin{array}{l}\text { circ- } \\
\text { ARSP91 }\end{array}$ & NK cell & $\begin{array}{l}\text { increasing the susceptibility of HCC cells to NK cell cytotoxicity by upregulating } \\
\text { UL16 binding protein } 1 \text { (ULBP1) expression in HCC cells at the mRNA and } \\
\text { protein levels }\end{array}$ & Hepatocellular Carcinoma & [63] \\
\hline $\begin{array}{l}\text { circ__ } \\
0000175\end{array}$ & Neutrophil & $\begin{array}{l}\text { significantly differentially expressed in rheumatoid arthritis, and are related to } \\
\text { disease activity and severity }\end{array}$ & Rheumatoid Arthritis & [64] \\
\hline \multicolumn{5}{|l|}{$\begin{array}{l}\text { circ_- } \\
0008410\end{array}$} \\
\hline- & Neutrophil & $\begin{array}{l}\text { Differentially expressed circRNAs were mainly involved in immune responses, } \\
\text { angiogenesis and metabolism in asymptomatic Moyamoya disease }\end{array}$ & Moyamoya Disease & [65] \\
\hline circ- & B cell & serving as the miR-7 "sponge" to increase expression of PTEN and restrain & SLE & [66] \\
\hline
\end{tabular}


Table 1 circular RNAs in immune responses and diseases (Continued)

\begin{tabular}{|c|c|c|c|c|}
\hline circRNA & $\begin{array}{l}\text { Immune cell } \\
\text { types }\end{array}$ & Potential Functions & Diseases or Process & Reference \\
\hline $\begin{array}{l}\text { circ_ } \\
102584\end{array}$ & - & as novel non-invasive biomarkers for SLE & SLE & {$[67]$} \\
\hline $\begin{array}{l}\text { circ } \\
0057980 \\
\text { circ_ } \\
0001045\end{array}$ & - & $\begin{array}{l}\text { circ-0057980 } \\
\text { serving as the miR-181d "sponge" to suppress the development of RA. } \\
\text { circ-0001045 serving as the miR-30a "sponge" to promote the biogenesis of RA }\end{array}$ & RA & [68] \\
\hline $\begin{array}{l}\text { circ_ } \\
0088088\end{array}$ & - & serving as the miR-16 "sponge" to suppress the development of RA & RA & [69] \\
\hline circ-Atp9b & - & serving as the miR-138 "sponge" to promote extracellular matrix degradation & $\mathrm{OA}$ & {$[70]$} \\
\hline $\begin{array}{l}\text { circ_ } \\
0005105\end{array}$ & - & $\begin{array}{l}\text { promoting extracellular matrix (ECM) degradation by regulating the expression of } \\
\text { miR-26a target NAMPT }\end{array}$ & $\mathrm{OA}$ & [71] \\
\hline $\begin{array}{l}\text { circ } \\
0045714\end{array}$ & - & $\begin{array}{l}\text { regulating extracellular matrix synthesis as well as proliferation and apoptosis of } \\
\text { chondrocytes by promoting the expression of miR-193b target gene IGF1R }\end{array}$ & $\mathrm{OA}$ & [72] \\
\hline circ-IBTK & - & $\begin{array}{l}\text { inhibiting DNA demethylation and activation of AKT signaling pathway by } \\
\text { binding to miR-29b }\end{array}$ & SLE & [73] \\
\hline $\begin{array}{l}\text { circ } \\
0045272\end{array}$ & - & $\begin{array}{l}\text { combining with miR-6127 to target PAX8 and DTX4 to participate in the secre- } \\
\text { tion of interleukin } 2 \text { and the negative regulation of apoptosis }\end{array}$ & SLE & {$[74]$} \\
\hline \multirow[t]{2}{*}{-} & \multirow[t]{2}{*}{-} & $\begin{array}{l}\text { circRNAs involved in atrial fibrillation due to rheumatic heart disease through } \\
\text { ceRNA mechanism }\end{array}$ & \multirow[t]{2}{*}{ Rheumatic } & \multirow[t]{2}{*}{ [75] } \\
\hline & & Infection related & & \\
\hline $\begin{array}{l}\text { circ } \\
0000479\end{array}$ & - & $\begin{array}{l}\text { indirectly regulating RIG-I expression by sponging miR-149-5p, hampering viral } \\
\text { replication }\end{array}$ & Hantaan Virus Infection & {$[76]$} \\
\hline $\begin{array}{l}\text { circ- } \\
\text { FNDC3B }\end{array}$ & \multirow[t]{2}{*}{-} & \multirow{2}{*}{$\begin{array}{l}\text { promoting MERS-COV load and their target mRNA expression which modulates } \\
\text { various biological pathways, including the mitogen-activated protein kinase } \\
\text { (MAPK) and ubiquitination pathways. }\end{array}$} & \multirow[t]{2}{*}{$\begin{array}{l}\text { MERS-CoV } \\
\text { Infection }\end{array}$} & \multirow[t]{2}{*}[77]{} \\
\hline circ-CNOT1 & & & & \\
\hline $\begin{array}{l}\text { circ } \\
0004812\end{array}$ & - & $\begin{array}{l}\text { circ_0004812/miR-1287-5p/FSTL1 axis regulated HBV-induced immune } \\
\text { suppression }\end{array}$ & $\begin{array}{l}\text { Chronic Hepatitis B } \\
\text { Infection }\end{array}$ & [78] \\
\hline $\begin{array}{l}\text { circ } \\
002423\end{array}$ & - & $\begin{array}{l}\text { the biological functions of genes hosting the circRNAs were enriched in the } \\
\text { progression of metabolism and binding }\end{array}$ & $\begin{array}{l}\text { Meningoencephalitis of } \\
\text { Teleosts }\end{array}$ & [79] \\
\hline \multicolumn{5}{|l|}{$\begin{array}{l}\text { circ } \\
002834\end{array}$} \\
\hline \multicolumn{5}{|l|}{$\begin{array}{l}\text { circ } \\
006192\end{array}$} \\
\hline \multicolumn{5}{|l|}{$\begin{array}{l}\text { circ } \\
007265\end{array}$} \\
\hline \multicolumn{5}{|l|}{$\begin{array}{l}\text { circ } \\
000305\end{array}$} \\
\hline \multicolumn{5}{|l|}{$\begin{array}{l}\text { circ } \\
006456\end{array}$} \\
\hline- & - & $\begin{array}{l}\text { circRNAs participating in the development of bacterial meningitis through } \\
\text { circRNA / miRNA / mRNA regulation mechanism }\end{array}$ & Bacterial Meningitis & {$[80]$} \\
\hline- & - & $\begin{array}{l}\text { circRNAs participating in the resistance to the pathogenesis of diarrhea through } \\
\text { circRNA / miRNA / mRNA regulation mechanism }\end{array}$ & $\begin{array}{l}\text { Diarrhea (Escherichia coli } \\
\text { F17) }\end{array}$ & {$[81]$} \\
\hline $\begin{array}{l}\text { circ }_{-} \\
001937\end{array}$ & - & correlated with tuberculosis severity & $\begin{array}{l}\text { Mycobacterium } \\
\text { tuberculosis infection }\end{array}$ & {$[82]$} \\
\hline - & - & $\begin{array}{l}\text { peripheral blood mononuclear cell circRNAs are potentially reliable marker } \\
\text { molecules in tuberculosis diagnosis }\end{array}$ & $\begin{array}{l}\text { Mycobacterium } \\
\text { tuberculosis infection }\end{array}$ & {$[83]$} \\
\hline $\begin{array}{l}\text { circ_ } \\
0005836\end{array}$ & - & $\begin{array}{l}\text { significantly down-regulated in the peripheral blood mononuclear cells of active } \\
\text { pulmonary tuberculosis compared with health controls, and might serve as a } \\
\text { novel potential biomarker for tuberculosis infection }\end{array}$ & $\begin{array}{l}\text { Mycobacterium } \\
\text { tuberculosis infection }\end{array}$ & {$[84]$} \\
\hline
\end{tabular}

Abbreviations:SCID Severe combined immunodeficiency, SLE Systemic lupus erythematosus, RA Rheumatoid arthritis, OA Osteoarthritis, LUAD Lung adenocarcinoma, PAAD Pancreatic adenocarcinoma, HCC Hepatocellular Carcinoma 
(LUAD) cells for trigger T-cell exhausting process. Note that circ_002178 can be delivered into $\mathrm{CD}^{+} \mathrm{T}$ cells to trigger PD1 expression via exosomes [47]. It was identified that the expressions of CXCR4, HIF1A, ZEB1, and $\mathrm{SDC} 1$ in pancreatic adenocarcinoma (PAAD) were controlled by circ-UBAP2 and miR-494. The expressions of CXCR4 and ZEB1 were related to the levels of Tregulating cells (Tregs) and consumed $\mathrm{T}$ cells in the PAAD tissues. The expressions of CXCR4 and ZEB1 were positively related to those of CTLA-4 and PD-1 [55], indicating the circUBAP2-mediated ceRNA system regulates $\mathrm{PAAD}$ by regulating the infiltrating process and functions of $\mathrm{CD} 8^{+} \mathrm{T}$ cells .

\section{circRNAs in macrophage activation}

As a vital part of innate immunity, macrophages are critical to host homeostasis and can change host phenotype and function in accordance with different conditions. Macrophages respond to microenvironmental signals with different activating process, covering conventional activating process exhibiting pro-inflammatory phenotypes (i.e., Ml) and polarimetric activation (M2) featuring an anti-inflammatory spectrum [86, 87]. Classically polarized M1 macrophages activate transitional cells by interferon-gamma (IFN- $\gamma$ ) or other microbial products, e.g., limited partners in turn generate pro-inflammatory cytokines at high levels (e.g., tumor necrosis factor-alpha (TNF), leukocytes Interleukin (IL)-12, IL-23, IL-6, IL-1 $\beta$, and intermediates generate reactive oxygen species and nitrogen at high concentrations [88-90]. M1 macrophages, as induction and effector cells, promote Th1 response and mediate resistance to intracellular parasites and tumor cells. In contrast, IL-4, IL-13 or immunecomplex induced activation of M2 macrophages suggested low IL-4, IL-13 production phenotypes and high IL-10, Arg-1, Fizz1 and Mrc-1 levels [91, 92]. Interestingly, Zhang et al. drew the comparison of circRNA expression spectrum source of bone marrow macrophage (BMDMs) under two diverse polarization (M1 interferon gamma and LPS stimulation attributed to macrophages, M2 macrophages triggered by interleukin - 4), and reported 189 circRNAs various expression for M1 and M2 macrophages, significantly demonstrating the real effect of circRNAs on macrophage polarization [93].

Growing evidence showed that circRNAs are vital in combination with macrophages in the advancement of certain diseases, the most common of which is cancer. Circ-ASAP1 was reported to facilitate HCC cell proliferating and invading processes by regulating miR-326/ miR-532-5p-MAPK1 signaling and mediate tumorrelated-macrophage infiltrating process through the control over the miR-326/miR-532-5p-CSF-1 path. Clinical HCC samples suggested positive associations between circ-ASAP1 expression and levels of CSF-1, MAPK1, and $\mathrm{CD}_{68}{ }^{+}$tumor-related-macrophages; all these could predict patient outcomes [57]. As suggested previously, Circ-UBAP2 also impacted M2 macrophages activation in the PAAD [55]. Zou Y et al. initially conducted a bioinformatics study on circ-CDR1as among 868 cancer samples with RNA-seq datasets of the MiOncoCirc database. Their data strongly suggests that circ-CDR1as may specifically impact immune and stromal cell infiltrating process in tumor tissue, especially those of $\mathrm{CD} 8^{+} \mathrm{T}$ cells, Natural killer (NK) cells stimulated, M2 macrophages, cancer-related fibroblasts (CAFs) and endothelial cells. Systematic and overall studies on circ-CDR1as were conducted to shed light on its underlying pro-cancerous system. Circ-CDR1as controls the TGF- $\beta$ signaling path and ECM-receptor interacting process to mediate the alerting process of the tumor microenvironment [54].

The relationships between circRNAs and macrophages have been reported in non-tumor diseases as well. Chen $\mathrm{X}$ et al. aimed to explore the system of the over activating process of osteoclasts that causes bone homeostasis to be deregulated under non-coding RNA regulating process. Patterns of circRNAs under differential expression were determined in non-treated and $\mathrm{RANKL}^{+}$ CSF1-treated bone marrow monocyte/macrophage (BMM) cells. They reported that circ_28313 relieves miR-195a-mediated inhabitation on CSF1 through being a ceRNA, thus conducting the modulation of the osteoclast differentiating process in BMM cells [94]. Huang Z et al. characterized circRNAs expression profiles in human monocyte derived macrophages (MDMs) response to Mycobacterium (Mtb) tuberculosis (TB) infection by microarray assay. As indicated in their outcomes, numerous circRNAs exhibited differential expression in human MDMs after Mtb infection. They found that circ 0043497 and circ_0001204 may be effective diagnostic biomarkers for TB, initially evidencing that circRNAs alterations take part in human MDMs response to TB infection and uncover underlying targets to diagnose and treat TB [58]. The LPS-induced cytoplasmic circRNA, mcircRasGEF1B, and integrate mcircRasGEF1B depletion targeted by transcriptomic study with high throughput to expound its function during the cellular response to LPS stimulating process was stressed and knockdown of mcircRasGEF1B causes modified expression of a wide array of genes. The mentioned results broaden the set of described circRNAs in a functional manner and prove the regulating effect of mcircRasGEF1B in immune response during macrophage activating process and protecting process against microbial infections [95]. Circular antisense non-coding RNA in the INK4 locus (circ-ANRIL), undergoing the transcription at a locus of atherosclerotic cardiovascular disease on chromosome 9 p21, endows atheroprotection through the modulation of pathways of atherogenesis and the control over 
ribosomal RNA (rRNA) maturation. Circ-ANRIL binds to pescadillo homologue 1 (PES1), a critical 60Spreribosomal assembly element, thereby adversely impacting exonuclease-mediated pre-rRNA processing and ribosome biogenesis in vascular smooth muscle cells and macrophages. Thus, circ-ANRIL gives rise to nucleolar stress and p53 activating process, thereby leading to the inducting process of apoptosis and inhibiting process of proliferation, i.e., critical cell functions in atherosclerosis. Overall, the mentioned findings report circ-ANRIL as a prototype of a circRNA controlling ribosome biogenesis and endowing atheroprotection, thus indicating that circularization of long non-coding RNAs may protect human from disease and modify RNA function [59].

\section{circRNAs and other immune cells}

This study delved into CircRNA of AR-hindered PABPC1 91 bp (circ-ARSP91), on immune surveillance triggered by NK cells. Circ-ARSP91 can enhance innate immune surveillance through the increase in the cytotoxicity of NK cells, suggesting that circRNA is likely to impact tumor immunity [63]. Gaffo E et al. found circRNA expression in B-cells, T-cells and monocytes of healthy subjects, covering assumed novel circRNA genes. The comparison of expression considered 6228 circRNAs and stressed cell population-specific expression and exon usage patterns. Differential expression was demonstrated by qRT-PCR for circRNAs specific of Bcells (circ-PAX5, circ-AFF3, circ-IL4R, and circSETBP1) or T-cells (circ-IKZF1, circ-TNIK, circ-TXK, and circ-FBXW7), and for circRNAs from intronic (circ$\mathrm{BCL2}$ ) and intergenic regions with overexpression in lymphocytes. Based on this resource of circRNA expression in mature blood cell groups, striking and generalized enriched expression of circ-PAX5, circ-PVT1 and circ-HIPK3 in pediatric B-precursor acute lymphoblastic leukemia were found in targeted examining process, and circRNAs exhibiting variable expression across cytogenetic subtypes were revealed [56]. Ma Q et al. delved into the circRNA expressing profile of neutrophil transcriptome in cases carrying asymptomatic Moyamoya disease (MMD). The circRNAs exhibiting differential expression primarily took part in immune responses, angiogenesis and metabolism in asymptomatic MMD [65]. GDF15 was expressed in Dendritic cells (DCs). GDF15 knockout facilitated malat-1 circular RNA (circ_Malat 1), immune responsive functions, DC maturation, while activating the nuclear factor kappa B (NF-kB) pathway [62].

\section{circRNAs in viral and bacterial infections}

According to recently conducted research, circRNA expressions were adversely affected in viral infections and circRNAs were likely to be antiviral targets. Hantaan virus (HTNV), common in Asia, induces hemorrhagic fever having renal syndrome (HFRS) that exhibits large mortality in human race. Some differently expressed RNAs (e.g., GBP1, PARP10, CMPK2, RIG-I, miR-411-3p, miR-330-5p, miR-149-5p, and circ_0000479, facilitated or suppressed HTNV replication). Circ_0000479 regulated RIG-I expression in an indirect manner by sponging miR-149-5p, hindering viral replicating process, which expounds the systems underpinning HTNV-host interaction [76]. Zhang $\mathrm{X}$ et al. delved into the host ceRNA network variations and biology-related associations of circRNAs in human lung adenocarcinoma epithelial (Calu-3) cells under the infection of the highly pathogenic Middle East respiratory syndrome coronavirus (MERS-CoV). $\geq 49,337$ putative circRNAs were assessed. Of the 7845 genes generating putative circRNAs, 147 (1.9\%) of these genes produced $\geq 30$ putative circRNAs, respectively, and took part in a wide range of metabolic, cellular, and biological processes, covering viral infections. Specific siRNA knockdown of two taken DE circRNAs (circ-FNDC3B and circ-CNOT1) noticeably down-regulated MERS-CoV load and their target mRNA expression, thus modulating a wide variety of biological pathways, covering the ubiquitination and mitogen-activated protein kinase (MAPK) pathways. The mentioned results expound the potential host-targeting antiviral strategies for MERS-CoV infection, biological relevance of circRNAs, and ceRNA network perturbations [77]. Extents of circ_0004812 were enriched in chronic hepatitis B (CHB) cases and HBV-infected hepatoma cells. circ_0004812 knockdown enriched the expression of IFN- $\alpha$ and IFN- $\beta$ in HBV-infected Huh7 cells. Circ_0004812/miR-1287-5p/FSTL1 axis-controlled HBV-induced immune inhibition [78].

Moreover, circRNAs are demonstrated to be involved in bacterial infections. Yang $\mathrm{R}$ et al. employed the sequencing method with high throughput to analyze the transcriptional profiles of host circRNAs in primary brain microvascular endothelial cells that respond to meningitic E. coli. 308 circRNAs received significant alteration in total, covering 140 enriched and 168 decreased ones. Through clarifying the transcriptional profiles of the host circRNAs taking part in E. coli meningitis, it is speculated that the new knowledge in the regulating systems of circRNAs in the progress of bacterial meningitis will help explain the method of preventing and treating bacterial infections [80]. circ 0005836 and circ_0009128 were significantly reduced in the peripheral blood mononuclear cells (PBMCs) of active pulmonary tuberculosis (APTB) in contrast to health controls (HC) [84]. Hu M et al. established circRNA expression profiles of persistent atrial fibrillation(AF) in cases carrying rheumatic heart disease. Circ_19591, circ 19596 and circ_16175 showed interactions to 36, 28, and 18 miRNAs, respectively; miR-29b-1-5p and miR-29b-2- 
$5 p$ displayed associations with 12 reduced circRNAs, respectively, which proposes an emerging perspective on circRNAs that participate part in AF for rheumatic heart disease and then lays a foundation for subsequent studies on the probable effects of circRNAs on AF [75].

\section{Conclusions and future perspective}

CircRNA in the immune system exhibit several functions: a. regulating the differentiation and development of immune cells, as circRNA can interact with critical factors during immune cell differentiation to differentiate targeted cells; b. regulating the activation state of immune cells and maintaining the homeostasis of cells by regulating critical signaling proteins during cell activation; c. regulating disease response, and the occurrence and development of a series of diseases by regulating the relative balance between pathogens and immune cells and the apoptosis of cells. However, the exact system of action of circRNAs should be further studied. At present, the studies mostly employed RNA sequencing technology to discover novel circRNAs. The number of circRNAs identified is relatively large, how to find functional circRNA from it and clarify its regulating system is considered as the difficulty of circRNA study. This study considers that with the deepening of the study, a growing number of circRNAs involved in immune regulation will be identified. As its system of action is elucidated, new systems are also provided for understanding, and new targets are provided in treating autoimmune diseases, inflammatory diseases and cancers.

\footnotetext{
Abbreviations

circRNAs: circular RNA; miRNA: microRNA; RBPs: RNA-binding proteins; Ago: Argonaute protein; ORF: Open reading frame; IRES: Internal ribosome entry site; m6A: N6-methyl adenosine; FTO: Fat mass and obesity associated; RCD: Regulated cell death; ACR: Autophagy-related circular RNA; HCC: Hepatocellular carcinoma; MAZ: MYC-associated zinc finger protein; TG: Triglyceride; PPAR: Peroxisome proliferator-activated receptor; CRC: Colorectal cancer; DCs: Dendritic cells; NKs: Natural killer cells; FeNO: Fraction of exhaled nitric oxide; TILs: Tumor infiltrating lymphocytes; LUAD: Lung adenocarcinoma; Tregs: T-regulatory cells; TNF: Tumor necrosis factor; IL: Leukocytes Interleukin; BMDMs: Bone marrow macrophage; CAFs: Cancer-associated fibroblasts; MDMs: Monocyte derived macrophages; Mtb: Mycobacterium; TB: Tuberculosis; circ-ANRIL: Circular antisense noncoding RNA in the INK4 locus; rRNA: Ribosomal RNA; PES1: Pescadillo homologue 1; circ-ARSP91: CircRNA of AR-suppressed PABPC1 91 bp; MMD: Moyamoya disease; NF-kB: Nuclear factor kappa B; HTNV: Hantaan virus; MERS-CoV: Middle East respiratory syndrome coronavirus; $\mathrm{CHB}$ : Chronic hepatitis B; PBMCs: Peripheral blood mononuclear cells; APTB: Active pulmonary tuberculosis; HC: Health controls; AF: Atrial fibrillation; SCID: Severe combined immunodeficiency; SLE: Systemic lupus erythematosus.; OA: Osteoarthritis; PAAD: Pancreatic adenocarcinoma; MAP3K9: Mitogen-activated protein kinase kinase kinase 9; RIG-I: Retinoic acid inducible gene I; FSTL1: Follistatin-related protein 1; IFN: Interferon; CSF: Macrophage colony-stimulating factor; PES1: Pescadillo homologue 1; DNMT1: DNA methyltransferase 1; GDF15: Growth/differentiation factor 15; MAPK1: Mitogen-activated protein kinase 1; CXCR4: C-X-C chemokine receptor type 4; ZEB1: Zinc finger E-box-binding homeobox 1; CTLA4: Cytotoxic T-lymphocyte protein 4
}

\section{Acknowledgements}

None.

\section{Authors' contributions}

The manuscript has 3 first authors who have made the same contribution to the project. Dr. ZXL, YC and FW are responsible for collecting all information related to the research. Dr. YC is responsible for drawing various pictures. Dr. LLW contributed to the editing and revision of the manuscript. In addition, there are three corresponding authors in the manuscript. Dr. WWT and QW contributed to the design of research ideas and revision of the manuscript. Dr. HYC, QW and WWT are also responsible for processing the revised draft and resubmitting the revised draft. The final manuscript read and approved by all authors.

\section{Funding}

This work was granted by Jiangsu Natural Science Foundation (SBK2019021253).

\section{Availability of data and materials}

No applicable.

Ethics approval and consent to participate

No applicable.

\section{Consent for publication}

No applicable.

\section{Competing interests}

The authors declare that they have absolutely no competing interests.

\section{Author details}

${ }^{1}$ Department of Hand Surgery, Plastic Surgery and Aesthetic Surgery, Ludwig-Maximilians University, Munich, Germany. ²Department of General Surgery, Nanjing First Hospital, Nanjing Medical University, Nanjing, Jiangsu, China.

Received: 7 May 2020 Accepted: 25 June 2020

Published online: 10 July 2020

\section{References}

1. Sanger HL, Klotz G, Riesner D, et al. Viroids are single-stranded covalently closed circular RNA molecules existing as highly base-paired rod-like structures. Proc Natl Acad Sci U S A. 1976;73:3852-6.

2. Chen LL, Yang L. Regulation of circRNA biogenesis. RNA Biol. 2015;12(4): $381-8$.

3. Yuan $X$, Yuan $Y$, He $Z$, et al. The regulatory functions of circular RNAs in digestive system cancers. Cancers (Basel). 2020;12(3):E770

4. Cui C, Yang J, Li X, et al. Functions and mechanisms of circular RNAs in cancer radiotherapy and chemotherapy resistance. Mol Cancer. 2020;19(1):58.

5. Guria A, Sharma P, Natesan S, et al. Circular RNAs-the road less traveled. Front Mol Biosci. 2020;6:146.

6. Shi $X$, Wang B, Feng $X$, et al. circRNAs and Exosomes: a mysterious frontier for human Cancer. Mol Ther Nucleic Acids. 2020;19:384-92.

7. Guidi R, Wedeles CJ, Wilson MS. ncRNAs in type-2 immunity. Noncoding RNA. 2020:6(1):E10.

8. Wells AC, Pobezinskaya EL, Pobezinsky LA. Non-coding RNAs in CD8 T cell biology. Mol Immunol. 2020;120:67-73.

9. Memczak S, Jens M, Elefsinioti A, et al. Circular RNAs are a large class of animal RNAs with regulatory potency. Nature. 2013:495(7441):333-8.

10. Hansen $\mathrm{TB}$, Jensen $\mathrm{TI}$, Clausen $\mathrm{BH}$, et al. Natural RNA circles function as efficient microRNA sponges. Nature. 2013;495(7441):384-8.

11. Jung $E$, Seong $Y$, Jeon $B$, et al. Global analysis of AGO2-bound RNAs reveals that miRNAs induce cleavage of target RNAs with limited complementarity. Biochim Biophys Acta Gene Regul Mech. 2017;1860(11):1148-58.

12. Wang Z, Lei X, Wu FX. Identifying Cancer-specific circRNA-RBP binding sites based on deep learning. Molecules. 2019;24(22):4035.

13. Ashwal-Fluss R, Meyer M, Pamudurti NR, et al. circRNA biogenesis competes with pre-mRNA splicing. Mol Cell. 2014;56(1):55-66.

14. Gupta SK, Garg A, Bär C, et al. Quaking inhibits doxorubicin-mediated Cardiotoxicity through regulation of cardiac circular RNA expression. Circ Res. 2018;122(2):246-54

15. Rybak-Wolf A, Stottmeister C, Glazar P, et al. Circular RNAs in the mammalian brain are highly abundant, conserved, and dynamically expressed. Mol Cell. 2015;58(5):870-85. 
16. Lei $M$, Zheng $G$, Ning $Q$, et al. Translation and functional roles of circular RNAs in human cancer. Mol Cancer. 2020;19(1):30.

17. Legnini I, Di Timoteo G, Rossi F, et al. Circ-ZNF609 is a circular RNA that can be translated and functions in myogenesis. Mol Cell. 2017;66(1):22 37.e9.

18. Yang $Y$, Fan $X$, Mao $M$, et al. Extensive translation of circular RNAs driven by N6-methyladenosine. Cell Res. 2017;27(5):626-41.

19. Galimov ER, Lohr JN, Gems D. When and how can death be an adaptation? Biochemistry (Mosc). 2019;84:1433-7.

20. Lee Y, Overholtzer M. After-death functions of cell death. Yale J Biol Med. 2019;92:687-94.

21. Zhai B, Hu F, Jiang X, et al. Inhibition of Akt reverses the acquired resistance to sorafenib by switching protective autophagy to autophagic cell death in hepatocellular carcinoma. Mol Cancer Ther. 2014;13(6):1589-98.

22. Zhou LY, Zhai M, Huang Y, et al. The circular RNA ACR attenuates myocardial ischemia/reperfusion injury by suppressing autophagy via modulation of the Pink1/ FAM65B pathway. Cell Death Differ. 2019;26(7): 1299-315.

23. Nie J, Lin B, Zhou M, et al. Role of ferroptosis in hepatocellular carcinoma. J Cancer Res Clin Oncol. 2018;144(12):2329-37.

24. Zhang HY, Zhang BW, Zhang ZB, et al. Circular RNA TTBK2 regulates cell proliferation, invasion and ferroptosis via miR-761/TTGB8 axis in glioma. Eur Rev Med Pharmacol Sci. 2020;24(5):2585-600.

25. Li Q, Pan X, Zhu D, et al. Circular RNA MAT2B promotes glycolysis and malignancy of hepatocellular carcinoma through the miR-338-3p/PKM2 Axis under hypoxic stress. Hepatology. 2019;70(4):1298-316.

26. Li H, Yang F, Hu A, et al. Therapeutic targeting of circ-CUX1/EWSR1/MAZ axis inhibits glycolysis and neuroblastoma progression. EMBO Mol Med. 2019;11(12):e10835.

27. Guo XY, Sun F, Chen JN, et al. circRNA_0046366 inhibits hepatocellular steatosis by normalization of PPAR signaling. World J Gastroenterol. 2018; 24(3):323-37.

28. Jin X, Feng CY, Xiang Z, Chen YP, Li YM. CircRNA expression pattern and circRNA-miRNA-mRNA network in the pathogenesis of nonalcoholic steatohepatitis. Oncotarget. 2016;7(41):66455-67.

29. Yang C, Kim HS, Song G, et al. The potential role of exosomes derived from ovarian cancer cells for diagnostic and therapeutic approaches. J Cell Physiol. 2019;234(12):21493-503.

30. Li Y, Zheng Q, Bao C, et al. Circular RNA is enriched and stable in exosomes: a promising biomarker for cancer diagnosis. Cell Res. 2015;25(8):981-4.

31. Wang G, Liu W, Zou Y, et al. Three isoforms of exosomal circPTGR1 promote hepatocellular carcinoma metastasis via the miR449a-MET pathway. EBioMedicine. 2019;40:432-45.

32. Zhang $\mathrm{H}$, Deng $\mathrm{T}$, Ge $\mathrm{S}$, et al. Exosome circRNA secreted from adipocytes promotes the growth of hepatocellular carcinoma by targeting deubiquitination-related USP7. Oncogene. 2019;38(15):2844-59.

33. Xu N, Chen S, Liu Y, et al. Profiles and bioinformatics analysis of differentially expressed Circrnas in Taxol-resistant non-small cell lung Cancer cells. Cell Physiol Biochem. 2018;48(5):2046-60.

34. Liu YY, Zhang LY, Du WZ. Circular RNA circ-PVT1 contributes to paclitaxel resistance of gastric cancer cells through the regulation of ZEB1 expression by sponging miR-124-3p. Biosci Rep. 2019;39(12):BSR20193045.

35. Zhang Y, Xue W, Li X, et al. The biogenesis of nascent circular RNAs. Cell Rep. 2016;15(3):611-24

36. Liu W, Ma WM, Yuan Y, et al. Circular RNA hsa_circRNA_103809 promotes lung cancer progression via facilitating ZNF121-dependent MYC expression by sequestering miR-4302. Biochem Biophys Res Commun. 2018;500:846-51.

37. Bian $L$, Zhi XF, Ma LL, et al. Hsa_circRNA_103809 regulated the cell proliferation and migration in colorectal cancer via miR-532e3p / FOXO4 axis. Biochem Biophys Res Commun. 2018;505:346-52.

38. Zhang PL, Zuo ZG, Shang WJ, et al. Identification of differentially expressed circular RNAs in human colorectal cancer. Tumor Biol. 2017;39(3): 1010428317694546

39. Song LL, Xiao Y. Downregulation of hsa_circ_0007534 suppresses breast cancer cell proliferation and invasion by targeting miR-593/MUC19 signal pathway. Biochem Biophys Res Commun. 2018;503:2603-10.

40. Russell CD, Unger SA, Walton $M$, et al. The human immune response to respiratory syncytial virus infection. Clin Microbiol Rev. 2017;30(2):481-502.

41. Ngono AE, Shresta S. Immune response to denque and Zika. Annu Rev Immunol. 2018;26(36):279-308.

42. O'Sullivan D, Sanin DE, Pearce EJ, et al. Metabolic interventions in the immune response to cancer. Nat Rev Immunol. 2019;19(5):324-35.
43. Nguyen MT, Götz F. Lipoproteins of gram-positive Bacteria: key players in the immune response and virulence. Microbiol Mol Biol Rev. 2016;80(3):891-903.

44. Qiu CC, Caricchio R, Gallucci S. Triggers of autoimmunity: the role of bacterial infections in the extracellular exposure of lupus nuclear autoantigens. Front Immunol. 2019;10:2608.

45. Martin TC, llieva KM, Visconti A, et al. Dysregulated antibody, natural killer cell and immune mediator profiles in autoimmune thyroid diseases. Cells. 2020;9(3):665.

46. McKinney EF, Lee JC, Jayne DR, et al. T-cell exhaustion, co-stimulation and clinical outcome in autoimmunity and infection. Nature. 2015;523(7562):612-6.

47. Wang J, Zhao X, Wang Y, et al. circRNA-002178 act as a ceRNA to promote PDL1/PD1 expression in lung adenocarcinoma. Cell Death Dis. 2020;11 (1):32.

48. Wang YH, Yu XH, Luo SS, et al. Comprehensive circular RNA profiling reveals that circular RNA100783 is involved in chronic CD28-associated CD8(+)T cell ageing. Immun Ageing. 2015;12:17.

49. Cassani B, Mirolo M, Cattaneo F, et al. Altered intracellular and extracellular signaling leads to impaired T-cell functions in ADA-SCID patients. Blood. 2008;111(8):4209-19.

50. Huang Z, Cao Y, Zhou M, et al. Hsa_circ_0005519 increases IL-13/LL-6 by regulating hsa-let-7a-5p in CD4(+) T cells to affect asthma. Clin Exp Allergy. 2019;49(8):1116-27.

51. Zhang C, Wang X, Chen Y, et al. The down-regulation of hsa_circ_0012919, the sponge for miR-125a-3p, contributes to DNA methylation of CD11a and CD70 in CD4(+) T cells of systemic lupus erythematous. Clin Sci (Lond). 2018;132(21):2285-98.

52. Deng L, Liu G, Zheng C, et al. Circ-LAMP1 promotes T-cell lymphoblastic lymphoma progression via acting as a ceRNA for miR-615-5p to regulate DDR2 expression. Gene. 2019;701:146-51.

53. Liu CX, Li X, Nan F, et al. Structure and degradation of circular RNAs regulate PKR activation in innate immunity. Cell. 2019;177(4):865 880.e21.

54. Zou Y, Zheng S, Deng $X$, et al. The role of circular RNA CDR1as/ciRS-7 in regulating tumor microenvironment: a pan-cancer analysis. Biomolecules. 2019;9(9):429.

55. Zhao R, Ni J, Lu S, et al. CircUBAP2-mediated competing endogenous RNA network modulates tumorigenesis in pancreatic adenocarcinoma. Aging (Albany NY). 2019;1 1(19):8484-501.

56. Gaffo E, Boldrin E, Dal Molin A, et al. Circular RNA differential expression in blood cell populations and exploration of circRNA deregulation in pediatric acute lymphoblastic leukemia. Sci Rep. 2019;9(1):14670.

57. Hu ZQ, Zhou SL, Li J, et al. Circular RNA sequencing identifies CircASAP1 as a key regulator in hepatocellular carcinoma metastasis. Hepatology. 2019. https://doi.org/10.1002/hep.31068.

58. Huang Z, Su R, Deng Z, et al. Identification of differentially expressed circular RNAs in human monocyte derived macrophages response to Mycobacterium tuberculosis infection. Sci Rep. 2017;7(1):13673.

59. Holdt LM, Stahringer A, Sass K, et al. Circular non-coding RNA ANRIL modulates ribosomal RNA maturation and atherosclerosis in humans. Nat Commun. 2016;7:12429.

60. Zhou Z, Jiang $R$, Yang $X$, et al. circRNA mediates silica-induced macrophage activation via HECTD1/ZC3H12A-dependent Ubiquitination. Theranostics. 2018;8(2):575-92.

61. Maass PG, Glazar P, Memczak S, et al. A map of human circular RNAs in clinically relevant tissues. J Mol Med (Berl). 2017;95(11):1179-89.

62. Zhang Y, Zhang G, Liu Y, et al. GDF15 regulates Malat-1 circular RNA and inactivates NFkB signaling leading to immune Tolerogenic DCs for preventing Alloimmune rejection in heart transplantation. Front Immunol. 2018:9:2407.

63. Ma Y, Zhang C, Zhang B. Et al.circRNA of AR-suppressed PABPC1 91 bp enhances the cytotoxicity of natural killer cells against hepatocellular carcinoma via upregulating UL16 binding protein 1. Oncol Lett. 2019;17(1): 388-97.

64. Luo Q, Zeng L, Zeng L, et al. Expression and clinical significance of circular RNAs hsa_circ_0000175 and hsa_circ_0008410 in peripheral blood mononuclear cells from patients with rheumatoid arthritis. Int J Mol Med. 2020;45(4):1203-12.

65. Ma Q, Li L, Yu B, et al. Circular RNA profiling of neutrophil transcriptome provides insights into asymptomatic Moyamoya disease. Brain Res. 2019; 1719:104-12.

66. Wu XN, Ye YX, Niu JW, et al. Defective PTEN regulation contributes to B cell hyperresponsiveness in systemic lupus erythematosus. Sci Transl Med. 2014; 6(246):246ra99. 
67. Li H, Li K, Lai W, et al. Comprehensive circular RNA profiles in plasma reveals that circular RNAs can be used as novel biomarkers for systemic lupus erythematosus. Clin Chim Acta. 2018;480:17-25.

68. Zheng F, Yu X, Huang J, et al. Circular RNA expression profiles of peripheral blood mononuclear cells in rheumatoid arthritis patients, based on microarray chip technology. Mol Med Rep. 2017;16(6):8029-36.

69. Murata K, Yoshitomi H, Tanida S, et al. Plasma and synovial fluid microRNAs as potential biomarkers of rheumatoid arthritis and osteoarthritis. Arthritis Res Ther. 2010;12(3):R86.

70. Zhou ZB, Du D, Huang GX, et al. Circular RNA Atp9b, a competing endogenous RNA, regulates the progression of osteoarthritis by targeting miR-138-5p. Gene. 2018;646:203-9.

71. Wu Y, Zhang Y, Zhang Y, et al. CircRNA hsa_circ_0005105 upregulates NAMPT expression and promotes chondrocyte extracellular matrix degradation by sponging miR-26a. Cell Biol Int. 2017;41(12):1283-9.

72. Li BF, Zhang Y, Xiao J, et al. Hsa_circ_0045714 regulates chondrocyte proliferation, apoptosis and extracellular matrix synthesis by promoting the expression of miR-193b target gene IGF1R. Hum Cell. 2017;30(4):311-8.

73. Wang X, Zhang C, Wu Z, et al. CirclBTK inhibits DNA demethylation and activation of AKT signaling pathway via miR-29b in peripheral blood mononuclear cells in systemic lupus erythematosus. Arthritis Res Ther. 2018; 20(1):118.

74. Li LJ, Zhu ZW, Zhao W, et al. Circular RNA expression profile and potential function of hsa_circ_0045272 in systemic lupus erythematosus. Immunology. 2018;155(1):137-49.

75. Hu M, Wei X, Li M, et al. Circular RNA expression profiles of persistent atrial fibrillation in patients with rheumatic heart disease. Anatol J Cardiol. 2019; 21(1):2-10.

76. Lu S, Zhu N, Guo W, et al. RNA-Seq revealed a circular RNA-microRNAmRNA regulatory network in Hantaan virus infection. Front Cell Infect Microbiol. 2020;10:97.

77. Zhang X, Chu H, Wen L, et al. Competing endogenous RNA network profiling reveals novel host dependency factors required for MERS-CoV propagation. Emerg Microbes Infect. 2020;9(1):733-46.

78. Zhang L, Wang Z. Circular RNA hsa_circ_0004812 impairs IFN-induced immune response by sponging miR-1287-5p to regulate FSTL1 in chronic hepatitis B. Virol J. 2020;17(1):40.

79. Fan B, Chen F, Li Y, et al. A comprehensive profile of the tilapia (Oreochromis niloticus) circular RNA and circRNA-miRNA network in the pathogenesis of meningoencephalitis of teleosts. Mol Omics. 2019;15(3): 233-46.

80. Yang R, Xu B, Yang B, et al. Circular RNA Transcriptomic analysis of primary human brain microvascular endothelial cells infected with Meningitic Escherichia coli. Mol Ther Nucleic Acids. 2018;13:651-64.

81. Jin C, Bao J, Wang Y, et al. Changes in circRNA expression profiles related to the antagonistic effects of Escherichia coli F17 in lamb spleens. Sci Rep. 2018;8(1):14524.

82. Huang ZK, Yao FY, Xu JQ, et al. Microarray expression profile of circular RNAs in peripheral blood mononuclear cells from active tuberculosis patients. Cell Physiol Biochem. 2018;45(3):1230-40.

83. Qian Z, Liu H, Li M, et al. Potential diagnostic power of blood circular RNA expression in active pulmonary tuberculosis. EBioMedicine. 2018;27:18-26.

84. Zhuang ZG, Zhang JA, Luo HL, et al. The circular RNA of peripheral blood mononuclear cells: Hsa_circ_0005836 as a new diagnostic biomarker and therapeutic target of active pulmonary tuberculosis. Mol Immunol. 2017;90: 264-72.

85. Weng Q, Chen M, Li M, et al. Global microarray profiling identified hsa_circ 0064428 as a potential immune-associated prognosis biomarker for hepatocellular carcinoma. J Med Genet. 2019;56(1):32-8.

86. Salmaninejad A, Valilou SF, Soltani A, et al. Tumor-associated macrophages: role in cancer development and therapeutic implications. Cell Oncol. 2019; 42(5):591-608.

87. Yao $Y, X u X H$, Jin L. Macrophage polarization in physiological and pathological pregnancy. Front Immunol. 2019;10:792

88. Shapouri-Moghaddam A, Mohammadian S, Vazini H, et al. Macrophage plasticity, polarization, and function in health and disease. J Cell Physiol. 2018;233(9):6425-40

89. Xie C, Liu C, Wu B, et al. Effects of IRF1 and IFN- $\beta$ interaction on the M1 polarization of macrophages and its antitumor function. Int J Mol Med. 2016:38(1):148-60
90. Hao NB, Lü MH, Fan YH, et al. Macrophages in tumor microenvironments and the progression of tumors. Clin Dev Immunol. 2012;2012:948098.

91. Huang Y, Du KL, Guo PY, et al. IL-16 regulates macrophage polarization as a target gene of mir-145-3p. Mol Immunol. 2019;107:1-9.

92. Hu S, Fu X, Fu A, et al. The regulatory peptide pidotimod facilitates M2 macrophage polarization and its function. Amino Acids. 2014;46(5):1177-85.

93. Zhang Y, Zhang Y, Li X, et al. Microarray analysis of circular RNA expression patterns in polarized macrophages. Int J Mol Med. 2017;39(2):373-9.

94. Chen X, Ouyang Z, Shen Y, et al. CircRNA_28313/miR-195a/CSF1 axis modulates osteoclast differentiation to affect OVX-induced bone absorption in mice. RNA Biol. 2019;16(9):1249-62.

95. Ng WL, Marinov GK, Chin YM, et al. Transcriptomic analysis of the role of RasGEF1B circular RNA in the TLR4/LPS pathway. Sci Rep. 2017;7(1):12227.

\section{Publisher's Note}

Springer Nature remains neutral with regard to jurisdictional claims in published maps and institutional affiliations.
Ready to submit your research? Choose BMC and benefit from:

- fast, convenient online submission

- thorough peer review by experienced researchers in your field

- rapid publication on acceptance

- support for research data, including large and complex data types

- gold Open Access which fosters wider collaboration and increased citations

- maximum visibility for your research: over $100 \mathrm{M}$ website views per year

At $\mathrm{BMC}$, research is always in progress.

Learn more biomedcentral.com/submissions 